\title{
COVID-19 pandemic accelerated virtual transformation in dental education: a multicenter review of remote teaching and teledentistry
}

\author{
Transformação virtual acelerada pela pandemia de COVID-19 \\ na educação odontológica: uma revisão multicêntrica \\ do ensino à distância e da teleodontologia
}

\author{
Constanza E. FERNÁNDEZ1 ${ }^{1}$ iD https://orcid.org/0000-0003-0979-7637 \\ Eder A. SIGUA-RODRIGUEZ2 ${ }^{2}$ iD https://orcid.org/0000-0002-7971-9856 \\ Clara I. VERGARA-HERNÁNDEZ3 ${ }^{3}$ iD https://orcid.org/0000-0002-6834-813X \\ Victor H. TORAL-RIZO4 ID https://orcid.org/0000-0003-0839-0771 \\ Gustavo TELLO5 ${ }^{\text {iD }}$ https://orcid.org/0000-0003-0120-6388 \\ Cristhian C. MADRID TROCONIS ${ }^{6}$ iD https://orcid.org/0000-0003-4058-1447 \\ Sthefanie PEREZ PUELLO ${ }^{7}$ iD https://orcid.org/0000-0001-9145-8217 \\ Gina D. ROQUE-TORRES ${ }^{8}$ iD https://orcid.org/0000-0003-3848-4891
}

\section{ABSTRACT}

Although prior to the pandemic there was some resistance to the virtualization of dental education, the COVID-19 pandemic is providing us a unique opportunity to overcome several barriers that previously blocked the adoption of remote teaching and teledentistry. Thanks to the extended availability of telecommunications, digital technologies, and platforms, remote education and teledentistry appear to be the preferred choice to maintain dental education and patient care active under this pandemic, without contamination risks. In

$\nabla \nabla \nabla$

1 Universidade de Talca, Faculdade de Ciencias da Saúde, Escola de Odontologia, Departamento de Reabilitação Oral, Unidade de Cariologia. 1 Poniente 1141 Talca, Chile.

2 Instituição Universitaria Colegios de Colombia, Departmento de investigação (CICO). Bogotá, Colombia.

${ }^{3}$ Universidade de Cartagena, Departamento de Medicina e Cirurgia Oral Medicine. Cartagena, Bolívar, Colômbia.

${ }^{4}$ Universidade Autonoma do Estado de Mexico, Faculdade de Odontologia, Centro de Pesquisa e Estudos Avancados de Odontologia. Toluca de Lerdo, México.

5 Universidade Norbert Wiener, Departamento de Odontopediatría. Lima, Perú.

${ }^{6}$ Universidade de Cartagena, Departmento de Reabilitação Oral, Faculdade de Odontologia, Campus da Saúde. Cartagena, Bolívar, Colômbia.

${ }^{7}$ Corporação Universitaria Rafael Nunhes, Departamento de Odontologia Social e Comunitaria, Escola de Ciências da Saúde. Cartagena, Bolívar, Colômbia.

${ }^{8}$ Universidade de Loma Linda, Escola de Odontologia, Centro de Pesquisa Odontologica. 11175 Campus Street, Chan Shun Pavilion, Loma Linda, CA 92350, Estados Unidos, USA. Correspondence to: GD ROQUE-TORRES. E-mail: <gdrtorres@llu.edu>.

$\boldsymbol{\nabla} \boldsymbol{\nabla} \boldsymbol{\nabla}$

How to cite this article

Fernández CE, Sigua-Rodriguez EA, Vergara-Hernández Cl, Toral-Rizo VH, Tello G, Madrid Troconis CC, et al. COVID-19 pandemic accelerated virtual transformation in dental education: a multicenter review of remote teaching and teledentistry. RGO, Rev Gaúch Odontol. 2021;69:e20210027. http://dx.doi.org/10.1590/1981-86372021002920200171 
this paper, we review valid remote education strategies and possible alternatives useful in virtual transformation in dental education. Furthermore, the role of teledentistry and its advantages and challenges are also revised. Under the current pandemic context, as dental educators, we are called to be creative and flexible. Every dental school should adapt and use remote education as much as possible until clinical attention can be readopted. The evidence presented in this review supports our position that under this pandemic, remote education and telemedicine/teledentistry may be "the virtual convenient solution", to adapt and improve the hitherto classic way of teaching dentistry through tele-education.

Indexing terms: Dentistry. Telemedicine. Telecommunications. Videoconferencing.

\section{RESUMO}

Embora antes da pandemia houvesse alguma resistência à virtualização da educação odontológica, a pandemia COVID-19 está nos fornecendo uma oportunidade única de superar várias barreiras que anteriormente bloqueavam a adoção do ensino à distância e teledontologia. Graças à ampla disponibilidade de telecomunicações, tecnologias digitais e plataformas, a educação à distância e a teledontologia parecem ser a escolha preferida para manter a educação odontológica e o atendimento ativo aos pacientes durante a pandemia, sem riscos de contaminação. Neste artigo, revisamos estratégias válidas de educação a distância e possíveis alternativas úteis na transformação virtual na educação odontológica. Além disso, o papel do teleodontologia e suas vantagens, assim como também os desafios. No atual contexto pandêmico, como educadores odontológicos, somos chamados a ser criativos e flexíveis. Cada escola de odontologia deve se adaptar e usar a educação à distância, tanto quanto possível, até que a atenção clínica possa ser readotada. As evidências apresentadas nesta revisão corroboram nossa posição de que, sob esta pandemia, a educação a distância e a telemedicina / teleodontologia podem ser "a solução virtual conveniente", para adaptar e aprimorar a forma até então clássica de ensino de odontologia, agora por meio da teleducação.

Termos de indexação: Odontologia. Telemedicina. Telecomunicações. Comunicação por videoconferência.

\section{INTRODUCTION}

The COVID-19 pandemic has changed the way of teaching throughout the globe, and the "real" impact it has triggered on education [1] and health [2] remains uncertain. Social distancing measures have severely affected all aspects of life, including education. Due to the proximity between students and teachers in the educational system, most of the educational institutions needed to suspend or postpone their classroom activities in all fields and levels. As a result of this interruption in education, it is highly probable that most of the world is having some online teaching and learning activities. Institutions have been forced to provide remote education [1] to keep their programs active, including dental schools.

Furthermore, the lockdown of several dental schools and dental clinics has stopped professionals from providing dental/oral care to patients in need and instruction through student clinical practices. Therefore, in order to continue treating patients but reducing the risk of crosscontamination during face-to-face dental treatment, teledentistry strategies are an extremely useful approach [3]. Given the educational challenge that we are currently facing, this paper reviews valid remote education strategies and possible alternatives useful in the virtual transformation of dental education. Additionally, the role of teledentistry and how it can be performed will also be reviewed. The evidence presented in this review conducted as a collaboration between universities or research centers supports the position that under this pandemic, remote education and telemedicine/teledentistry may be "the virtual convenient solution" [4].

\section{Re-structuring dental education under COVID-19 pandemic}

This unpreceded crisis has been a challenge for education systems worldwide. These unprecedented circumstances have impacted most academic programs, originally developed and approved to be conducted via face-to-face interactions, they have now had to rapidly transform into virtual programs. Therefore, COVID-19 has accelerated the development of online education. Students initially enrolled and accustomed to inperson learning are now almost exclusively learning via remote education, often seen as a problematic learning environment. Fortunately, there now exists a plethora of technology and platforms that can be used to overcome the challenges due to COVID-19 [5] allowing a more seamless learning environment to complete their programs [6]. The already available technologies and platforms (table 1) 
Table 1. List of Web-based Platforms Available to Augment Remote Education.

\begin{tabular}{|c|c|c|c|}
\hline $\begin{array}{l}\text { Educacional } \\
\text { Platforms }\end{array}$ & $\begin{array}{l}\text { Videoconference } \\
\text { Platforms }\end{array}$ & $\begin{array}{l}\text { Web-based Audience } \\
\text { Response Systems }\end{array}$ & $\begin{array}{c}\text { Video Recording } \\
\text { (Asynchronous or Synchronous videos) }\end{array}$ \\
\hline $\begin{array}{l}\text { - Canvas } \\
\text { - Blackboard Learn } \\
\text { - Moodle } \\
\text { - Google Classroom } \\
\text { - STOA } \\
\text { - TalentLMS } \\
\text { - Schoology } \\
\text { - Edmodo } \\
\text { - Brightspace } \\
\text { - Sakai }\end{array}$ & $\begin{array}{l}\text { - Zoom } \\
\text { - Webex } \\
\text { - Google Meet } \\
\text { - Microsoft Teams } \\
\text { - ezTalks Meetings } \\
\text { - Join.me } \\
\text { - ReadyTalk } \\
\text { - OnStream } \\
\text { - GoToMeeting } \\
\text { - Demio } \\
\text { - BlueJeans }\end{array}$ & $\begin{array}{l}\text { - Polleverywhere } \\
\text { - Mentimeter } \\
\text { - Kahoot } \\
\text { - TopHat } \\
\text { - Ahaslides } \\
\text { - Slido } \\
\text { - MeetingPulse } \\
\text { - Beekast } \\
\text { - DirectPoll } \\
\text { - Participoll } \\
\text { - Wooclap } \\
\text { - Hypersay } \\
\text { - Engagenow }\end{array}$ & $\begin{array}{l}\text { - Camtasia, CamStudio } \\
\text { - VideoStrips } \\
\text { - Panopto (recording syncromic lectures/activities in CANVAS) } \\
\text { - Ezvid } \\
\text { - BlueBerry Flashback Express Recorder } \\
\text { - Screenr } \\
\text { - Rylstim Screen Recorder } \\
\text { - Krut } \\
\text { - Webineria }\end{array}$ \\
\hline
\end{tabular}

have facilitated the virtualization of dental education and education in general. The use of technology due to the COVID-19 pandemic is revolutionizing teaching techniques through distance learning.

\section{Advantages of Remote Education - Virtual solutions for COVID-19}

Remote education (also known as tele-teaching, virtual education, or online learning) is an alternative or complement to the classic face-to-face or classroom education. Countries like Japan, China, Australia, the United States, and Canada have used remote education in dental training for years [7-9]. On the other hand, there are countries with no previous experience in remote education that are currently struggling to implement it in such a short amount of time. Besides the advantages of remote education allowing dental education and clinical attention to continue remotely under the pandemic, another advantage of online learning is that it promotes the use of more flexible methodologies that contributes to quality education [10] (e.g. with the use of asynchronous material). Virtual communication also provides greater interaction during the educational process, expanding and reaching various areas of professional training and continuing education [11]. Evidence gathered from students in online learning environments shows that they felt more connected and supported [12]. With remote education, it is recommended to use a variety of strategies that include both synchronous (in real-time) and asynchronous (self-learning activities). However, interactive videoconferencing (synchronous) had better results than asynchronous because of its ability to provide immediate feedback [13]. Feedback detects possible problems during the educative process allowing educators to correct issues immediately. Teachers should follow up on student's participation and ideally elaborate or provide tutorials or guides that should be given to solve doubts or difficulties. The implementation of student's feedback strategies is a key factor for the success of remote education [10]. Under the context of this pandemic, the recommendation for educators is to be creative and create strategies and alternatives to allow students to develop their skills and to advance their competencies [14].

Remote education can also facilitate the globalization of education, establishing teaching activities that improve the education quality in places far away [15]. However, even with its multiple advantages, doubts remain about virtual classrooms being adequate substitutes for modern faceto-face learning [16], especially in dentistry. One concern is whether the accelerated implementation of remote education may negatively affect the quality of dental education. If the reversion to our pre-pandemic habits takes several months or years [17] it may be quite sometime before face-to-face education may reconvene. Therefore, it is necessary to start creating feasible methods that strengthen dental remote education to assure that trained dentists during this global calamity are competent and qualified.

\section{Challenges and disadvantages of remote education}

The main challenges for remote education are related to accessibility problems. These may be the 
result of geographic location causing a lack of network connectivity, or in fact, a lack of economic resources to acquire adequate technology or network connectivity. Such connectivity issues could lead to students failing to attend a synchronous meeting or to meet deadlines to deliver planned activities. Students dealing with such issues may feel at a disadvantage or intimidated by remote education [18] and thus have a difficult time keeping up [19]. Furthermore, these inequalities in remote education access can increase the social gap between students [20]. We believe that accessibility and improvements in technologies are essential for the proper development of this remote activity, as these difficulties can impair students learning process, increasing resistance to adapt to this new educational strategy, and reducing the effectiveness of this new educational environment.

Another challenge is the possible lack of training to implement remote education effectively [1]. With the extension of the pandemic, it is most likely that faculty have received ad hoc, but quick, training in online teaching. Probably few had received instruction in virtual learning environments prior to the pandemic. Nevertheless, for a successful implementation of remote education, faculty and students should be prepared for the change towards the use of technological devices to carry out the teachinglearning process [21]. To overcome these new challenges, students and faculty must be trained to confront this new way of learning through digital platforms [22]. Other challenges that have now arisen may include the psychological consequences of social confinement, the possible loss of family and loved ones to the disease, and the numerous other changes in everyone's lifestyles. Consequently, psychological support should also be provided to students [23].

In Dentistry, several topics and competencies need to be acquired in a three-dimensional, palpable, or faceto-face way; consequently, there are several obstacles to implement online learning in dental education. Clinical contexts in dentistry are a concern; thus, virtual teaching to dental students requires a different approach to teaching when it comes to self-study. Due to this, it is necessary to carefully evaluate which courses and in which program level the use of distance courses is plausible. Within the miscellany of subjects specific to dentistry, some of them have already been brought forward to the digital age, as is the case of oral radiology, oral surgery $[24,25]$ pediatric dentistry [26] implantology [24] orthodontia [11] prosthodontics [27] promotion and prevention [9] and endodontics [28].

\section{Resources, activities, and platforms for remote dental education}

Recommendations for virtual teaching in dental education include a variety of activities that promote student self-learning within a clinical context such as problem-based learning [29] case studies, [23] and selfreflection activities [30] as other practical (pre-clinical and clinical) activities are currently on hold. Consequently, a more flexible form of teaching and learning is required, which favors more student-centered activities, including group activities (virtual), discussions, active learning activities, and thus, limiting the use of traditional classes. This implies a conceptual and philosophical rethinking of the nature of teaching and learning, the roles of teachers, students, and teaching resources in post-digital learning communities [31].

Furthermore, dental programs include a large array of practical procedures to develop student's handskills, and those skills are difficult to learn from didactic materials alone; thus, educational videos are useful in dental teaching $[9,11,24,26-28]$. However, we know that videos and online teaching do not replace practical sessions to teach and learn hand-skills. Some online activities involve uploading materials; thus, students can participate in asynchronously using wikis, blogs, or e-mail. Many health professionals are currently exploring the use of virtual platforms (table 1) to promote e-learning [5]. Ideally, universities should provide their own recorded material [25] and include with the video some narrated PowerPoint presentations (Microsoft) [27]. This grants students the option of listening and reviewing lectures at their convenience [23]. The pandemic has seen the rise of a variety of technology-driven software, apps, or platforms with educational uses (several examples are shown in table 1). Social media platforms such as YouTube ${ }^{\circledR}$ and Vimeo® have contributed to the growing acceptance of different forms of online learning. Additional communication options include using cellphones to stay in touch, or e-mail to send homework or links to activities. Since several studies suggest that formative assessment could improve the learning process [32] and allow students to better understand and apply contents or competences, formative activities must be part of virtual teaching. The are several applications (e.g. web-based audience response systems, table 1) that allow for remote real-time participation; they are quite simple to use by both students and professors [33]. They are often used to engage students' participation while 
evaluating the understanding of concepts. Those could be used as formative activities, that are well designed should provide significant learning experiences. Evidence has shown that students' learning experience can be improved with the use of interactive online formative assessment activities [34]. In dentistry, those activities should ideally be connected to clinical implications and applications. It is feasible that these technological resources (table 1) are not only indispensable to efficiently addressing the problem of higher education while the pandemic persists, but they will also serve to improve teaching-learning in the immediate future.

\section{Open access digital knowledge}

As a result of the pandemic, the amount of shared knowledge in virtual platforms, including webinars for commercial purposes and open online courses, have considerably increased. Although free resources are important to complement education when used appropriately, free online material might not be prepared using valid or reliable evidence. Previous studies have reported that most students use free online information to reinforce their knowledge [35]. This can generate biases and errors in the learning process, but this should not be a reason for eliminating the use of these types of tools. Therefore, some authors [35] recommend using it with validated instructional material that prevents the spread of bad or poor practices. We recommend teaching students to filter online videos. Theoretically, based videos could be distinguished from those showing empirical techniques not supported by scientific evidence. Also, students must be trained in the cognitive ability to analyze the risk of bias of the information presented by commercial entities. To state it simply, we should prioritize information literacy. Furthermore, educators must also seek to stimulate/ encourage students to search for impactful scientific articles to accompany their learning. Although open online courses in a clinical discipline can be a viable strategy for distance education, student behavior, and dynamics within these new learning environments remain poorly understood [36].

\section{Assessment strategies in remote education: a call to be flexible}

Assessment of the quality of virtual education, which is more flexible than traditional face-to-face instruction, will help to evaluate the quality of teaching and learning online programs. In this virtual modality, there is room to use a variety of novel strategies for assessment, such as electronic portfolios, collaborative forums, inverted lectures, analysis of scientific articles, standardized tests, reports, essays, or workshops that require collaborative and asynchronous time work [37] among others. An electronic portfolio is a tool that can offer greater flexibility for students to demonstrate the achievement of their learning outcomes [38]. It is important to highlight that flexibility is needed for evaluations (e.g. deadlines, modify assessment systems [1] adapt academic calendars and curricula).

Remote education also requires evaluating the acquisition of the declared objectives or competencies by students to estimate its effectiveness [39]. In health disciplines, there is an essential need to assure that all graduated professionals have achieved the established standards. To ensure the effectiveness of remote education in dental programs, besides the evaluation methods mentioned above, we suggest creating a group of professor members who can identify students with low engagement and participation in virtual activities. This should be done in the early stages, to adopt preventive measures, providing support and alignment with the new virtual methodologies [40].

Summative and formative assessments are identified as a major challenge for education due to concerns about cheating and group testing in an unsupervised remote testing environment [39]. Take-home tests are not recommended to test lower taxonomy levels, instead, higher levels of taxonomy are preferred to reduce the risk of unethical behavior [41]. Although remote supervision is an option (e.g. Mett $\mathrm{l}^{\circledR}$ and ExamSoft $\circledast$ ) to help to eliminate most forms of academic dishonesty during computerized evaluations, it has a high cost. But, considering the possible benefits of those kinds of tools [42] they could become a valuable tool in dental schools. Ultimately, the desired scenario is that dental students act with professionalism in all stages of their careers, particularly in situations when dishonesty may occur. Institutions must provide clear rules about evaluations promoting individual student responsibility [43].

\section{Teledentistry: a solution for patient care under COVID-19 pandemic}

Many hospitals, clinics, and universities have implemented teledentistry as quickly as possible. Teledentistry 
combines telecommunication technology and dental care [13] to provide remote dental care, advice, or treatment via technology, not requiring direct personal contact [44] and it contributions have shown in various systematic reviews $[45,46]$. From the beginning of the use of teledentistry, its main benefit has been associated with increased access $[13,45,46,47]$ thereby contributing to reducing rural-urban healthcare inequalities [44]. Furthermore, teledentistry is a very useful and alternative method to increase access to specialized dental care in the form of referrals or assisting general dentists [45]. Currently, the main benefit of teledentistry is to protect against spreading the virus among patients, clinicians, and the community [4]. Both patients and professionals can perform telemedicine/teledentistry from their homes in a safe environment.

\section{Barriers and challenges in telehealth/teledentistry}

The implementation of teledentistry has demanded a comprehensive, committed, and strategic alignment within the whole healthcare environment. Fortunately, there now exists nearly sufficient network connectivity, digital technology, and various platforms that can facilitate the feasibility of teledentistry. Yet, much of the world was still probably unprepared for a modern digital approach to the management of the epidemic [48]. Current barriers and challenges include differing local regulations, lack of necessary hardware, technical resources, and conflicts with privacy issues [45]. But, the main barrier for teledentistry implementation appears to be payments and reimbursements for those medical/dental virtual attentions. Thus, many countries have initiated telehealth for free, though the cost associated with teledentistry supposed to be lower than clinical consultations [47]. Subsequently, teledentistry may be conducted with high quality at a lower cost compared to in person consults, due to advances in technology [45]. Another challenge for teledentistry implementation is to keep dental students and oral health professionals trained in teledentistry. To address this, awareness programs or training programs towards teledentistry have been recommended [46].

\section{Benefits and opportunities in telehealth/ teledentistry}

Because many organizations have recommended limiting dental care to emergencies and urgent care needs, possibly the most important benefit of teledentistry under the current context is the ability to have a quick and safe manner for dental professionals to deal with dental emergencies without the need to patients leave their houses. This form of teledentistry is called: "forward triage" [4] which involves screening patients before they arrive at emergency consults. Thus, patients can resolve their doubts without breaking their self-quarantine [4] and, consequently, reduce the possibility of infection by the SARS-CoV2 virus. These virtual solutions should be seen as an opportunity to increase the awareness of patients on/ about oral health. Furthermore, teledentistry can be used to promote oral health and educate patients.

As smartphones and the internet have become ubiquitous, their use is the simplest method to allow a clinician to establish a direct connection with a patient. The use of simple mobile applications allowing for instant messaging, including some social media platforms, can be useful to provide early oral diagnosis and followup [49]. Patients can also use other equipment (e.g. laptops, desktops, tablets) to connect via the internet. Thus, virtual health care strategies can be done without the need for new sophisticated infrastructure. When performing teledentistry, even though real-time live consultation is preferable to asynchronous one--because real-time consultation could potentially achieve better outcomes due to two-way communication (between patient-professional), the asynchronous consultations are potentially better or comparable, but with a lower cost. Although prior to the pandemic there was resistance to telehealth, health virtualization has become a way to provide health care that professionals and patients require [48]. Consequently, oral telemedicine or teledentistry appears to be a preferred choice to keep patient care activities throughout this pandemic [3].

\section{Future perspectives post pandemic for dental education}

As the evolution of COVID-19 remain uncertain, especially in some countries where the disease is still in an exponential phase, every institution must provide alternatives that allow for dentistry and dental education to remain active. As decisions worldwide are being based on local choices by institutions and population reality [30] the recommendation is for each institution to establish local alternatives to every possible scenario. The adoption of 
clear protocols of infection control strategies to guarantee the safety of students, teachers, and patients to reduce the risk of infection is necessary [50]. Furthermore, the profession should be adjusted as teledentistry and minimal intervention dentistry appear to play a pivotal role.

Although there are institutions in which all the hand-skills training is carried out on simulators, most schools use it prior to clinical practice on real patients. However, the use of simulation and simulation facilitators will help decrease the fear and pressure associated with the risk of contracting the virus [23]. Simulation-based dental education is an emerging component, showing benefits for student learning and training in dentistry [51]. Simulation methodologies such as augmented reality and virtual reality [51] are important for developing psychomotor skills [52]. Although computer-based simulation requires more research to use it as a conventional method for the instruction and evaluation of students [53] they are very promising and probably the future in dental education. The adoption of those strategies depends on the experience and skills of the teachers with such hardware, software use, plus economic resources. The implementation of those strategies must be critically evaluated by educational institutions and ideally supported by high impact and valid scientific evidence.

Other strategies and considerations to be adopted post-pandemic include the continued development and enhancement of open educational platforms that allow access to high-quality online learning resources; to execute research studies to assess the effect of online teaching and learning models on graduates in the workplace; to increase the efforts to guarantee faculty online training as well as supporting staff on online platforms; to create alliances and networks between national and international universities, between the private sector and society, and to promote high quality online learning in the community [54]. After the passing of the pandemic, maintaining remote modalities for both teaching and teledentistry appear to be positive avenues to augment dental education as well as regular dental care.

\section{CONCLUSION}

- COVID-19 has provided a unique opportunity to overcome several barriers that previously blocked the adoption of remote teaching and teledentistry, as both reduce the risk of crosscontamination.

- Online education provides an opportunity to rethink and improve upon the classic way of teaching dentistry.

- Teledentistry should be used to assure continuity of care to patients, especially those suffering from pain and discomfort, but also used to manage preventable oral diseases.

- Computer-based simulation or virtual reality appears to help to decrease the fear and pressure associated with the risk of contracting the virus. It is a very promising approach to complement training in dental clinics and probably the future in dental education.

\section{Acknowledgments}

The authors thank Luis E. Salazar for the review of the manuscript.

\section{REFERENCES}

1. Longhurst GJ, Stone DM, Dulohery K, Scully D, Campbell T, Smith CF. Strength, Weakness, Opportunity, Threat (SWOT) Analysis of the Adaptations to Anatomical Education in the United Kingdom and Republic of Ireland in Response to the Covid-19 Pandemic. Anat Sci Educ. 2020;13(3):301-311. http://dx.doi.org/10.1002/ase.1967

2. Wang Q, Su M. A preliminary assessment of the impact of COVID-19 on environment - A case study of China. Sci Total Environ. 2020;728:138915. http://dx.doi.org/10.1016/j. scitotenv.2020.138915

3. Maret $D$, Peters OA, Vaysse $F$, Vigarios $E$. Integration of telemedicine into the public health response to COVID-19 must include dentists. Int Endod J. 2020;53(6):880-881. http://dx.doi.org/10.1111/iej.13312

4. Hollander JE, Carr BG. Virtually Perfect? Telemedicine for Covid-19. N Engl J Med. 2020;382:1679-81. http://dx.doi. org/10.1056/NEJMp2003539

5. Ting DSW, Carin L, Dzau V, Wong TY. Digital technology and COVID-19. Nat Med. 2020;26(4):459-61. http://dx.doi. org/10.1038/s41591-020-0824-5

6. Carmo RDOS, Franco AP. Da docência presencial à docência online: aprendizagens de professores universitários na educação a distância. Educação Rev. 2019;35:e210399. http://dx.doi. org/10.1590/0102-4698210399

7. Andrews KG, Demps EL. Distance Education in the U.S. and Canadian Undergraduate Dental Curriculum. J Dental Educ. 2003;67:427-438. http://dx.doi.org/10.1002/j.00220337.2003.67.4.tb03644.x 
8. Schleyer T, Spallek H. Dental informatics. A cornerstone of dental practice. J Am Dent Assoc. 2001; 132:605-613. http:// dx.doi.org/10.14219/jada.archive.2001.0237

9. Silva AS, Rizzante FA, Picolini MM, Campos K, Correa CC, Franco EC, et al. Bauru School of Dentistry Tele-Health League: an educational strategy applied to research, teaching and extension among applications in tele-health. J Appl Oral Sci. 2011;19:599-603. http://dx.doi.org/10.1590/s167877572011000600009

10. van Schaik SM, Regehr G, Eva KW, Irby DM, O'Sullivan PS. Perceptions of peer-to-peer interprofessional feedback among students in the health professions. Acad Med. 2016;91:807-812. http://dx.doi.org/10.1097/ACM.0000000000000981

11. Lima MS, Tonial FG, Basei E, Brew MC, Grossmann E, Haddad $A E$, et al. Effectiveness of the distance learning strategy applied to orthodontics education: a systematic literature review. Telemed J E Health. 2019;25:1134-1143. http:// dx.doi.org/10.1089/tmj.2018.0286

12. Armstrong SN, Early JO, Burcin MM, Bolin K, Holland N, No S. New Media tools impact on online, health science students' academic persistence and support: lessons learned from two pilot studies. TechTrends. 2018;62:266-275. http://dx.doi. org/10.1007/s11528-018-0261-1

13. Chen JW, Hobdell MH, Dunn K, Johnson KA, Zhang J. Teledentistry and its use in dental education. J Am Dent Assoc. 2003;134(3):342-6. http://dx.doi.org/10.14219/jada. archive.2003.0164

14. Stuij SM, Drossaert CHC, Labrie NHM, Hulsman RL, Kersten MJ, van Dulmen $S$, et al. Developing a digital training tool to support oncologists in the skill of information-provision: a user centred approach. BMC Med Educ. 2020;20(1):135. http://dx.doi.org/10.1186/s12909-020-1985-0

15. Gonzales-Zamora JA, Alave J, De Lima-Corvino DF, Fernandez A. Videoconferences of Infectious Diseases: An educational tool that transcends borders. A useful tool also for the current COVID-19 pandemic. Infez Med. 2020;28(2):135-8. http:// dx.doi.org/10.1109/ICETAS.2018.8629177

16. Donkin R, Askew E, Stevenson H. Video feedback and e-Learning enhances laboratory skills and engagement in medical laboratory science students. BMC Med Educ. 2019;19(1):310. http://dx.doi.org/10.1186/s12909-019-1745-1

17. Kissler SM, Tedijanto C, Goldstein E, Grad YH, Lipsitch M. Projecting the transmission dynamics of SARS-CoV-2 through the postpandemic period. Science. 2020;368(6493):860-8. http://dx.doi.org/10.1126/science.abb5793

18. Darling-Hammond L, Flook L, Cook-Harvey C, Barron B, Osher D. Implications for educational practice of the science of learning and development. Appl Devel Sci. 2020;24(2):97-140. http:// dx.doi.org/10.1080/10888691.2018.1537791

19. Mian A, Khan S. Medical education during pandemics: a UK perspective. BMC Med. 2020;18(1):100. http://dx.doi. org/10.1186/s12916-020-01577-y

20. Meinert E, Milne-Ives M, Surodina S, Lam C. Agile Requirements Engineering and software planning for a digital health platform to engage the effects of isolation caused by social distancing: case study. JMIR Public Health Surveill. 2020;6(2):e19297. http://dx.doi.org/10.2196/19297
21. Sharma P, Maleyeff J. Internet education: potential problems and solutions. Int J Educ Manag. 2003;17:19-25. http:// dx.doi.org/10.1108/09513540310456365

22. Siddiquah A, Salim Z. The ICT Facilities, Skills, Usage, and the Problems Faced by the Students of Higher Education. EURASIA J Math Sci Tech Ed. 2017;13:4987-4994. http:// dx.doi.org/https://doi.org/10.12973/eurasia.2017.00977a

23. Meng L, Hua F, Bian Z. Coronavirus Disease 2019 (COVID-19): emerging and future challenges for dental and oral medicine. J Dent Res. 2020;99:481-487. http://dx.doi. org/10.1177/0022034520914246

24. Wagner F, Knipfer C, Holzinger D, Ploder O, Nkenke E. Webinars for continuing education in oral and maxillofacial surgery: The Austrian experience. J Craniomaxillofac Surg. 2019;47(4):537-41. http://dx.doi.org/10.1016/j.jcms.2019.01.009

25. Aldallal SN, Yates JM, Ajrash M. Use of YouTube as a self-directed learning resource in oral surgery among undergraduate dental students: a cross-sectional descriptive study. Br J Oral Maxillofac Surg. 2019;57(10):1049-52. http:// dx.doi.org/10.1016/j.bjoms.2019.09.010

26. Bavaresco CS, Braganca S, Vencato V, Feltes B, Soria GS, Brew $M C$, et al. Performance of primary healthcare dentists in a distance learning course in pediatric dentistry. Int J Med Inform. 2019;129:296-302. http://dx.doi.org/10.1016/j. ijmedinf.2019.06.014

27. Botelho MG. Evaluation of student use of videos to support learning in a simulation laboratory course: A perception and analytics approach. J Investig Clin Dent. 2019;10(4):e12453. http://dx.doi.org/10.1111/jicd. 12453

28. Kolcu MIB, Ozturkcu OSK, Kaki GD. Evaluation of a distance education course using the 4c-id model for continuing endodontics education. J Dent Educ. 2020;84(1):62-71. http://dx.doi.org/10.21815/JDE.019.138

29. Plancher KD, Shanmugam JP, Petterson SC. The Changing face of orthopedic education: searching for the new reality after COVID-19. Arthrosc Sports Med Rehabil. 2020;2(4):e295-e8. http://dx.doi.org/10.1016/j.asmr.2020.04.007

30. Quinn B, Field J, Gorter R, Akota I, Manzanares MC, Paganelli C, et al. COVID-19: the immediate response of European Academic Dental Institutions and future implications for dental education. Eur J Dent Educ. 2020;24(4):811-4. http:// dx.doi.org/10.1111/eje.12542

31. Kim CS, Lynch JB, Cohen S, Neme S, Staiger TO, Evans L, et al. One Academic Health System's Early (and Ongoing) Experience Responding to COVID-19: Recommendations From the Initial Epicenter of the Pandemic in the United States. Acad Med. 2020;95(8):1146-8. http://dx.doi.org/10.1097/ ACM.0000000000003410

32. Senye-Mir AM, Arumí-Prat J, Pla-Campas G, Ramírez E. Effects of Formative Assessment on the Learning-tolearn Skills of Teacher Training Students. Procedia - Social Beh Sci. 2016;228:196-201. http://dx.doi.org/https://doi. org/10.1016/j.sbspro.2016.07.029

33. Compton M, Allen J. Student response systems: a rationale for their use and a comparison of some cloud based tools. Compass: J Learn Teac 2018;2018;11(1). http://dx.doi. org/10.21100/compass.v11i1.696 
34. Bi Bijol V, Byrne-Dugan CJ, Hoenig MP. Medical student web-based formative assessment tool for renal pathology. Med Educ Online. 2015;20:26765. http://dx.doi.org/10.3402/ meo.v20.26765

35. Uribe S, Marino RJ. Internet and information technology use by dental students in Chile. Eur J Dent Educ. 2006;10:162-168. http://dx.doi.org/10.1111/j.1600-0579.2006.00412.x

36. Stich $A E$, Reeves TD. Massive open online courses and underserved students in the United States. Internet Higher Educ. 2017;32:58-71. http://dx.doi.org/https://doi. org/10.1016/j.iheduc.2016.09.001

37. Huang RH, Liu DJ, Tlili A, Yang JF, Wang HH. Handbook on facilitating flexible learning during educational disruption: the chinese experience in maintaining undisrupted learning in covid-19 outbreak. Beijing: Smart Learning Institute of Beijing Normal University; 2020.

38. Barbera E. Quality in virtual education environments. Br J Educ Technol. 2004;35:13-20. http://dx.doi.org/10.1111/j.14678535.2004.00364.x

39. Santos I, Carvalho AA. Formação e monitorização: duas etapas no desenvolvimento profissional docente. Educ \& Realidade. 2017;42:323-44. http://dx.doi.org/10.1590/2175623655298

40. Martins PV, da Silva AR. A case study applying process and project alignment methodology. J Braz Computer Soc. 2006;12:65-82. http://dx.doi.org/10.1007/BF03194496

41. Bengtsson L. Take-Home exams in higher education: a systematic review. Educ Sci. 2019;9:267. http://dx.doi.org/ https://doi.org/10.3390/educsci9040267

42. UNESCO. COVID-19 Educational Disruption and Response. UNESCO 2020 [cited 2020 April 17]. Available from: https:// en.unesco.org/covid19/educationresponse

43. Zheng M, Bender D. Evaluating outcomes of computer-based classroom testing: Student acceptance and impact on learning and exam performance. Medical Teacher. 2019;41:75-82. http://dx.doi.org/10.1080/0142159X.2018.1441984

44. Khan SA, Omar $\mathrm{H}$. Teledentistry in practice: literature review. Telemed J E Health. 2013;19:565-567. http://dx.doi. org/10.1089/tmj.2012.0200

45. Irving M, Stewart R, Spallek H, Blinkhorn A. Using teledentistry in clinical practice as an enabler to improve access to clinical care:
A qualitative systematic review. J Telemed Telecare. 2018;24: 129-146. http://dx.doi.org/10.1177/1357633X16686776

46. Alabdullah JH, Daniel SJ. A systematic review on the validity of teledentistry. Telemed J E Health. 2018;24: 639-648. http:// dx.doi.org/10.1089/tmj.2017.0132

47. Golder DT, Brennan KA. Practicing dentistry in the age of telemedicine. J Am Dent Assoc. 2000;131:734-744. http:// dx.doi.org/10.14219/jada.archive.2000.0272

48. Omboni S. Telemedicine During the covid-19 in Italy: a Missed opportunity? Telemed J E Health. 2020;26(8):973-5. http:// dx.doi.org/10.1089/tmj.2020.0106

49. Machado RA, de Souza NL, Oliveira RM, Martelli Junior $H$, Bonan PRF. Social media and telemedicine for oral diagnosis and counselling in the COVID-19 era. Oral Oncol. 2020;104685. http://dx.doi.org/10.1016/j.oraloncology.2020.104685

50. Volgenant CMC, Persoon IF, de Ruijter RAG, de Soet JJ. Infection control in dental health care during and after the SARS-CoV-2 outbreak. Oral Dis. 2020;27(Suppl 3):674-683. http://dx.doi.org/10.1111/odi.13408

51. Zafar S, Lai Y, Sexton C, Siddiqi A. Virtual Reality as a novel educational tool in pre-clinical paediatric dentistry training: Students' perceptions. Int J Paed Dent. 2020;30(6):791-7. http://dx.doi.org/10.1111/ipd.12648

52. Murbay S, Neelakantan P, Chang JWW, Yeung S. Evaluation of the introduction of a dental virtual simulator on the performance of undergraduate dental students in the pre-clinical operative dentistry course. Eur J Dent Educ. 2020;24(1):5-16. http://dx.doi.org/10.1111/eje.12453

53. Nassar HM, Tekian A. Computer simulation and virtual reality in undergraduate operative and restorative dental education: A critical review. J Dent Educ. 2020;84(7):812-829. http:// dx.doi.org/10.1002/jdd.12138

54. Zhu X, Liu J. Education in and After Covid-19: Immediate responses and long-term visions. Postdigital Sci Educ. 2020;26:1-5. http://dx.doi.org/10.1007/s42438-020-00126-3

Received on: 1/9/2020

Final version resubmitted on: 10/12/2020 Approved on: 19/2/2021 